\title{
Spring and Early Summer Temperatures in a Shallow Arctic Pond
}

\author{
H. V. DANKS ${ }^{1}$
}

\begin{abstract}
Temperatures were recorded continuously during spring and early summer in a shallow pond on Bathurst Island in the High Arctic; thawing was rapid. After the thaw seasonal and diel differences within the water and mud showed that frozen substrate had a marked effect on mud temperature, but that the superficial mud received almost as much heat as the water immediately above it. Temperature summations suggested that even in favourable shallow habitats low mud temperatures dictate the life-cycles of more than one year of arctic chironomids. The maximum-minimum temperature midpoint was a satisfactory substitute for a recorder-obtained day-mean, and seasonal comparisons of pond temperatures in relation to bottom fauna could therefore be based on daily maximum and minimum mud surface temperatures.
\end{abstract}

RÉSUMÉ. Températures du printemps et du début de l'été dans une mare peu profonde de l'Arctique. Dans une mare peu profonde, sur l'île de Bathurst dans le Haut Arctique, on a enregistré de façon continue les températures du printemps et du début de l'été. Après le dégel, les différences saisonnières et quotidiennes dans l'eau et dans la vase montrent que le substrat pergelé a un effet marqué sur la température de la vase, mais aussi que la vase superficielle reçoit presque autant de chaleur que l'eau qui la recouvre immédiatement. Les -compilations des températures suggèrent que même dans des habitats favorables parce que peu profonds, les basses températures de la vase dictent les cycles biologiques pluriannuels chez les chironomides de l'Arctique. La médiane des températures maximum et minimum peut être substituée à la température moyenne enregistrée; les températures maximum et minimum quotidiennes de la surface de la vase peuvent donc servir de base aux comparaisons saisonnières des températures de la mare en relation avec la faune $\mathrm{du}$ fond.

РЕЗЮМЕ. Данные измерения температуры в мелководном бассейне на острове Батерст. Приводятся данные беспрерывных ивмерений температуры, проведенных весной и ранним летом в мелководном бассейне на о-ве Батерст. Обсуждается влияние температуры воды -и ила на развитие донной фауны бассейна.

\section{INTRODUCTION}

Some temperature characteristics of small water bodies in the High Arctic have been given by Oliver and Corbet (1966) from studies made at Lake Hazen, Ellesmere Island. Their conclusions for shallow pond habitats were derived from continuous instrument records from 2 sites in a single pond, and from fixed daily "spot" measurements of surface water in a number of other ponds throughout the season. Some additional measurements are given by Corbet (1967).

1Entomology Research Institute, Canada Department of Agriculture, Ottawa, Ontario. 
This paper presents the results of continuous instrument measurements made during spring and early summer in a shallow pond on Bathurst Island, Northwest Territories. Records were made of bottom temperature in shallow water at different depths and of temperature in the surface mud zone. These records are relevant to the development of bottom-living pond organisms in the Arctic. The general conclusions advanced by Oliver and Corbet (1966) were confirmed, and the measurements of mud temperatures allowed some additional conclusions.
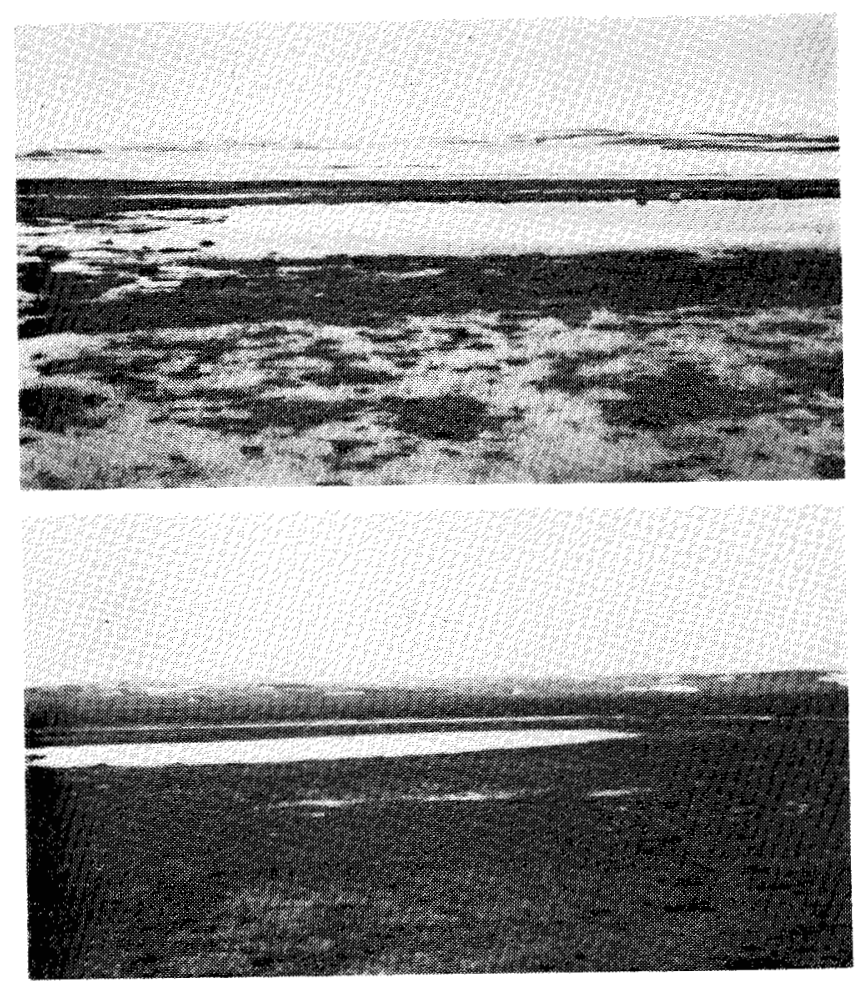

FIG. 1. Northern half of pond on 20 June 1969 , from west.

FIG. 2. Pond on 19 July 1969 , from northwest.

\section{DESCRIPTION OF HABITAT}

The pond studied (Figs. 1 and 2) lies at $75^{\circ} 43^{\prime} \mathrm{N}$., $98^{\circ} 28^{\prime} \mathrm{W}$. near the west bank of the Goodsir River at the eastern edge of a marshy area which extends along a valley lying between $98^{\circ} 25^{\prime} \mathrm{W}$. and $98^{\circ} 45^{\prime} \mathrm{W}$. This pond is maintained by drainage from part of the hillside forming the northern limit of the valley. Two smaller ponds immediately to the northwest are temporary. The pond is essentially a shallow basin, with a diameter of $30 \mathrm{~m}$., a maximum depth of $25 \mathrm{~cm}$., and a mean depth at spring maximum of $17 \mathrm{~cm}$. A soft muddy bottom predominates; it is little to moderately vegetated, although some areas are stony and the edges are characterized by a moss mat held together by salts deposited during summer drying out.

This pond is representative of a large number of small shallow but permanent ponds in the general marsh area, all with a very similar fauna. 


\section{METHODS}

Continuous chart records were obtained for the period 12 June to 18 July using a battery-driven thermograph, accurate to $\pm 1^{\circ} \mathrm{F}$. $\left(0.5^{\circ} \mathrm{C}\right.$.), described by Voisey et al. (1964). Results were obtained from each of 9 thermistor probes (Y.S.I. no. 401, interchangeable within $0.1^{\circ} \mathrm{C}$.), the outputs of which were recorded cyclically to give a complete set of readings about every 35 minutes. Comparative differences of much less than $\pm 0.5^{\circ} \mathrm{C}$. were also detectable between records made during the same cycle, and between successive records from the same probe. The charts were related to solar time, and the temperature of each probe taken from the record nearest to each solar hour. Other computations were made from these hourly records.

The pond was delineated in early June by probing through the snow cover. Probes were installed beneath snow, and into the pond ice. Since the probe wires have high absorptive power, they melt the snow around them during sunshine and so affect their position and the subsequent local disappearance of snow. The probes were not shielded during the thaw, and some additional measurements were therefore made with a dial thermometer. An estimate of the mean snow cover of the pond for each day was made from snow depth measurements at a number of sites. Several dial thermometer readings were made at $1200 \mathrm{hrs}$. under depths corresponding to the estimate and averaged to give a mean ice-surface temperature.

After the thaw, probes were relocated beneath different depths of water and mud. Most of the probes lay above or in the predominating softer, moderately vegetated areas of the pond bottom. The bottom in the shallowest area (near the margin) had a thick crust of vegetation because it was dry for part of the summer; the probes penetrating this zone were therefore in vegetation rather than mud. Probes were placed on the pond bottom, and at 1,2 and $5 \mathrm{~cm}$. depths into mud under three different depths of water. Water depth above the probes was measured at intervals to take account of changes in pond level caused by evaporation and rainfall.

Temperatures directly above the ground surface were measured in a sedge area immediately adjacent to the pond.

From the data obtained, maximum-minimum midpoints and day-means (see definitions below) were computed for different days and zones in order to assess the reliability of using the easily-obtained midpoint in place of the day-mean for such pond temperatures. In addition, day-means were used to compute mud temperature sums for estimation of the heat available to organisms in the pond mud. The major portion of the pond bottom fauna consisted of the larvae of chironomid midges, the adult emergence of which took place in two peaks, assayed by surface emergence traps (described in Corbet 1965). Summed temperatures for the different zones were therefore compared for the approximate developmental period from the thaw to the second emergence peak, the 25-day period 23 June to 17 July, during which overwintering larvae of the final instar of several species developed through the pupal stage to the adult. 


\section{Definitions}

Hour-mean:

\section{RESULTS}

Day-mean:

Period-mean:

average temperature for the same hour (solar time) over a number of days;

mean of 24 hourly temperatures for a given day;

mean temperature over a period of days, derived from the true or day-mean;

Maximum-minimum midpoint: average of the maximum and the minimum on a given day.

\section{Pond temperatures}

The first snow began to melt on the pond area in mid-June, and by 18 June the extreme edges $(10$ to $15 \mathrm{~cm}$.) were clear of snow and ice, with melt water above the central pond ice. The pond bottom inside the marginal (vegetated-crust) area was not exposed generally until after 20 June. The last traces of central ice melted on 24 June.

Fig. 3 shows the course of temperature (day-mean) from 12 to 22 June at the ice surface under 2 initial depths of snow (curves 2 and 3), and in the ice near the pond edge (curves 4 to 6 ). The rapidity of the thaw shown by these curves is confirmed (Fig. 3 inset) by dial thermometer measurements at the ice surface under the daily mean pond snow cover. This cover was initially $25 \mathrm{~cm}$., its small depth being accounted for by the exposed position of the pond. The temperature of the layer of air next to the ground is also shown (curve 1) for comparison with the pond temperature.

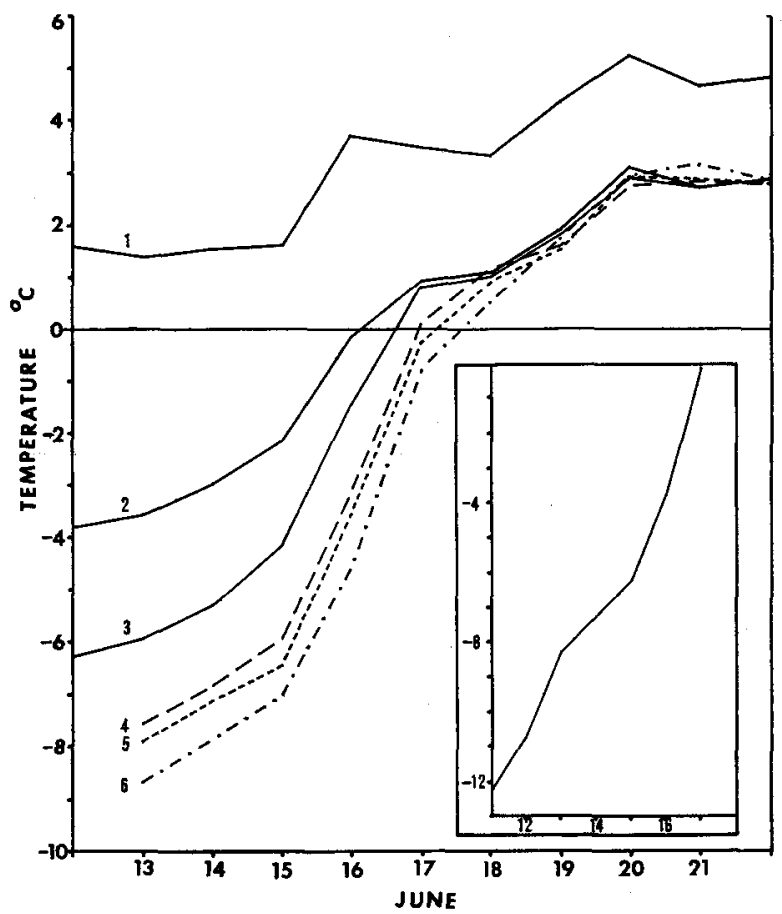

FIG. 3. Day-means during thaw. 1) ground surface. 2) under $10 \mathrm{~cm}$. snow initially. 3) $15 \mathrm{~cm}$. snow. 4) $12.5 \mathrm{~cm}$. snow, $2.5 \mathrm{~cm}$. ice. 5) $12.5 \mathrm{~cm}$. snow, $5 \mathrm{~cm}$. ice. 6) $12.5 \mathrm{~cm}$. snow, $15 \mathrm{~cm}$. ice (pond bottom). Inset: Dial-thermometer records (ice surface under mean snow cover). 
Although there was a strong upward trend of temperature during the thawing period, a distinct diel pattern was shown by the hour-means, with maxima at $1700 \mathrm{hrs}$. and minima at $0400 \mathrm{hrs}$. (solar time), except for the pond bottom under $15 \mathrm{~cm}$. ice where the mean maximum occurred at $1800 \mathrm{hrs}$.

Water and adjacent mud temperatures after the thaw were recorded from 23 June until $18 \mathrm{July}$. Fig. 4 compares successive day-means for the pond bottom (curve 2) and for the mud at 2 depths (curves 3 and 4) under the same mean depth of water, about $9 \mathrm{~cm}$. The ground surface temperatures are shown in curve 1. The variation in water level above the probes (as evaporation reduced the level from the spring peak, which was then restored by rainfall) is also shown. The fluctuation of the temperatures is very noticeable, and the fluctuations are synchronized between all zones. The differences between the colder deeper zones and the warmer shallower ones diminish as the season progresses, and this trend can be detected in Fig. 4 until at least mid-July.

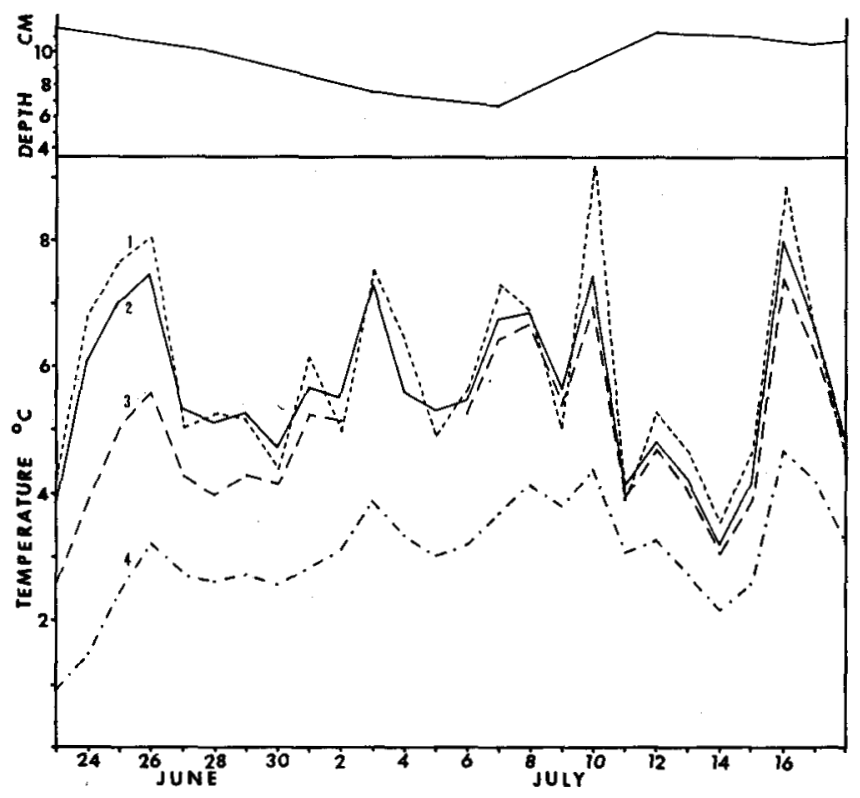

FIG. 4. Day-means after thaw, and water depth profile. 1) ground surface. 2) mean water depth of $9.0 \mathrm{~cm}$., pond bottom. 3) do., 2 cm. mud. 4) do., $5 \mathrm{~cm}$. mud.

Period-means at the mud surface were similar beneath different depths of water. Means beneath $4 \mathrm{~cm} ., 9 \mathrm{~cm}$. and $18.5 \mathrm{~cm}$. of water were $5.89^{\circ} \mathrm{C}$., $5.69^{\circ} \mathrm{C}$. and $5.56^{\circ} \mathrm{C}$. respectively, for the period $23 \mathrm{June}$ to $6 \mathrm{July}$. (This period was taken in order to include comparable data for the shallowest depth, records for which were discontinued when the level had fallen to less than $2 \mathrm{~cm}$. on $7 \mathrm{July}$.) At $2 \mathrm{~cm}$. into the mud, the period-mean for $23 \mathrm{June}$ to $17 \mathrm{July}$, in water $9 \mathrm{~cm}$. deep, was not lowered very markedly $\left(4.95^{\circ} \mathrm{C}\right.$.), but at $5 \mathrm{~cm}$. it was much lower $\left(3.06^{\circ} \mathrm{C}\right.$.). At the ground surface this period-mean was $5.92^{\circ} \mathrm{C}$., which is very close to that of the mud surface in the pond.

The daily patterns in the different zones have been compared by plotting hourmeans. Fig. 5 shows the difference between bottom temperatures under different depths of water for the period 23 June to 6 July. The differences between different 

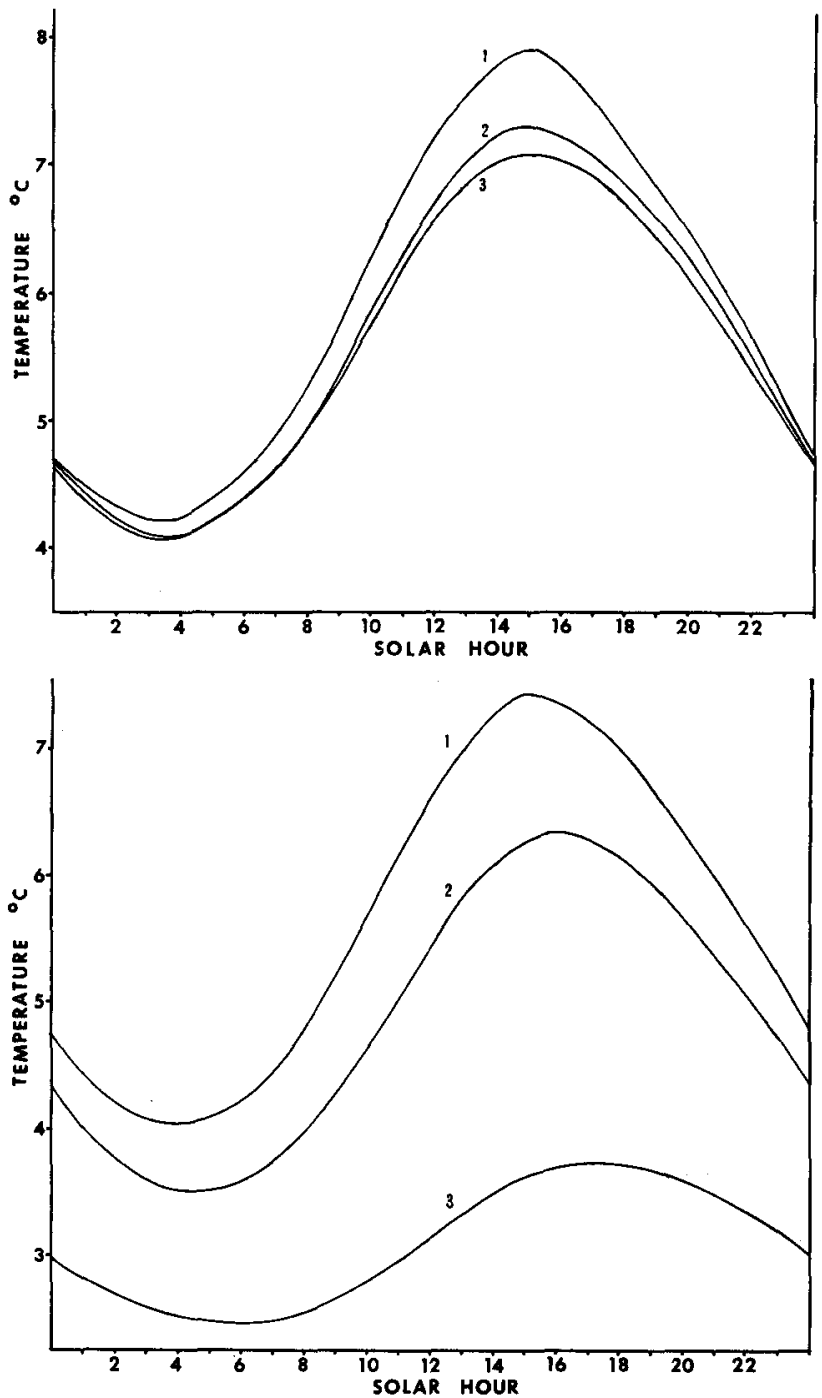

FIG. 5. Pattern of hour-means for water at the pond bottom at 3 depths (23.vi-6.vii). 1) $4.0 \mathrm{~cm}$. 2) $9.0 \mathrm{~cm} .3) 18.5 \mathrm{~cm}$.
FIG. 6. Pattern of hour-means for water at the pond bottom and mud in a mean depth of $9.0 \mathrm{~cm}$. (23.vi-17.vii). 1) pond bottom. 2) $2 \mathrm{~cm}$. mud. 3) $5 \mathrm{~cm}$. mud.

water depths are small, and the diel patterns are highly regular. Fig. 6 compares bottom temperature and mud temperatures in an average water depth of about $9 \mathrm{~cm}$. for the period 23 June to 17 July. Here the regular diel pattern shown is clearly displaced until later in the day in the deeper zones. This is most marked under $5 \mathrm{~cm}$. mud (curve 3 ).

The mean times of the maxima and minima (derived from the hour-means) for the 25-day period, and also the mean times calculated separately for the earlier and later parts of the period, are shown more precisely in Fig. 7. They confirm that in general the maximum and minimum were later in deeper water and mud zones. Fig. 7 shows also that early in the season compared to the later part of the period studied, the maximum was later and the minimum earlier in these deeper zones. 


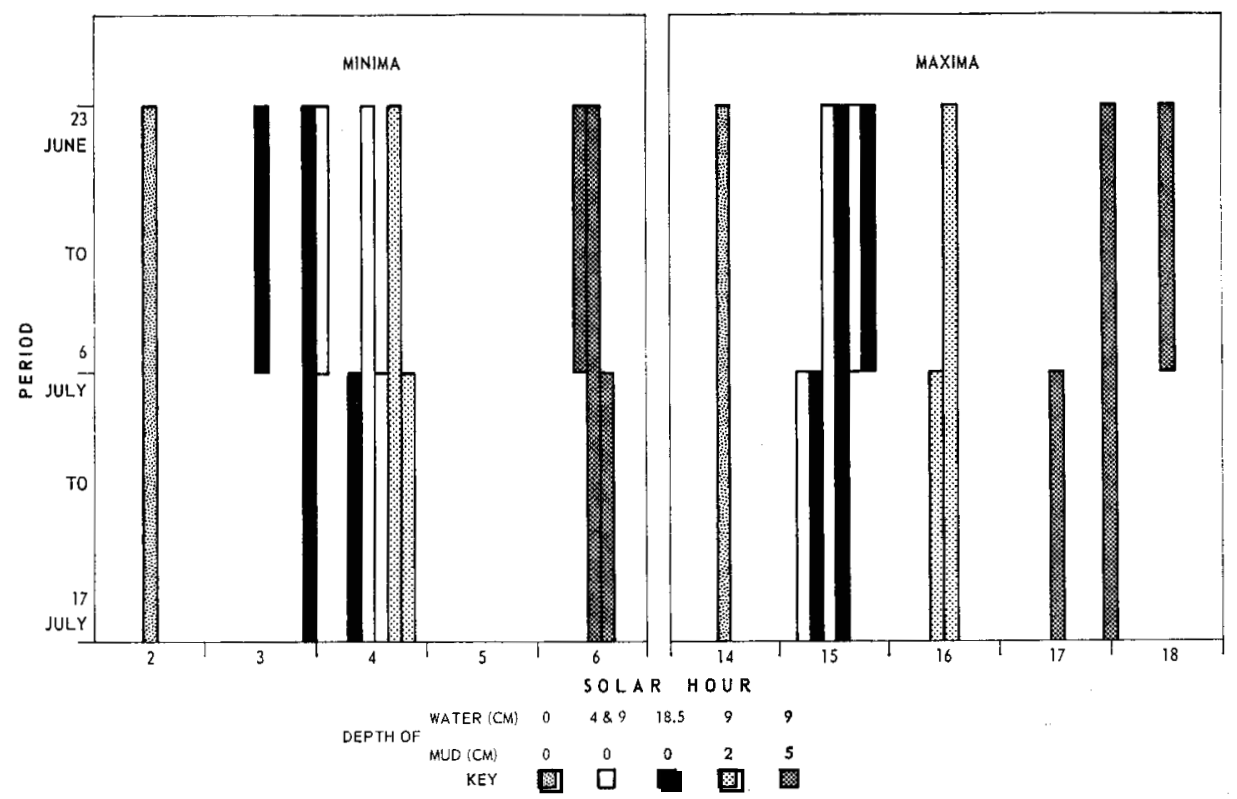

FIG. 7. Mean times of daily maxima and minima in different zones for the periods 23 June to 6 July; 7 July to 17 July; and 23 June to 17 July.

\section{Maximum-minimum midpoint/day-mean difference}

Analysis of the 271 pairs of records available (Table 1) showed that, except in shallower zones, agreement between the two parameters was rather close, and that the midpoint more often lay above than below the day-mean. The mean difference for the pond zones was $0.2 \mathrm{deg}$. C. and for the ground surface $0.6 \mathrm{deg}$. C., whereas the greatest difference on any one day was 4 to 5 times these figures.

TABLE 1. Distribution of the max.-min. midpoint/day-mean difference for various zones.

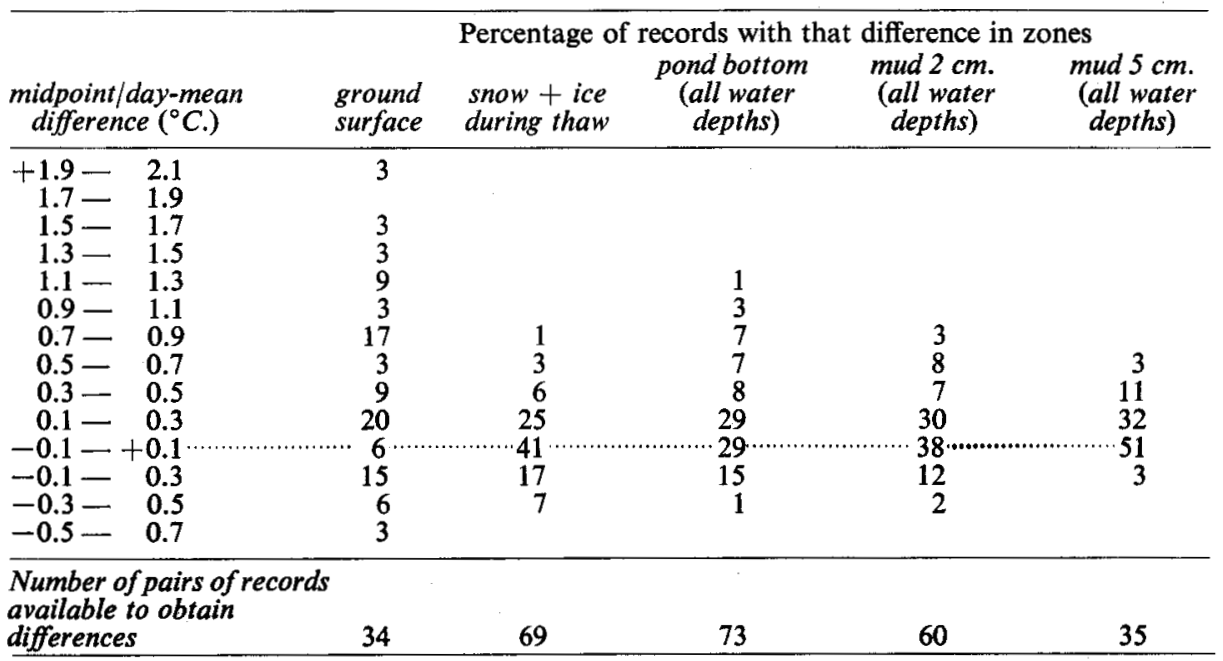


The analysis also revealed that the larger differences were recorded on days when the normal diel pattern was disturbed. This was due to a very hot day followed by a cloudy day, or a steady fall of cool rain, causing the "maximum" to precede the minimum; or to a short period of sunshine in an otherwise cloudy day. The disturbance of the diel pattern so produced was greatest in shallow zones, and especially at the ground surface.

\section{Temperature summation in bottom zones}

The day-degree values above $0^{\circ} \mathrm{C}$. for various zones are given in Table 2 . The day-degrees for the zones are also given as a percentage of those for the warmest zone in each group, using 3 different baselines. The percentages for a baseline of $0^{\circ} \mathrm{C}$. compare the values in the first column of the Table. For baselines of $2^{\circ} \mathrm{C}$. and $4^{\circ} \mathrm{C}$. they are based on values for the 25 -day period computed from the daymeans, disregarding days when the mean lay below the baseline. (Computation from the hour-means gives figures which are little different.) From the instrument's known absolute accuracy $\left( \pm 1^{\circ} \mathrm{F}\right.$.) the maximum possible error in these figures is \pm 14 day-degrees Centigrade: even this maximum error would not substantially affect the comparative conclusions below.

TABLE 2. Summed temperatures for different zones during post-thaw 25-day period (extrapolated from 14-day means for water depth and $1 \mathrm{~cm}$. mud comparisons); and amount for different zones as a percentage of the value for the warmest zone in each of the two groups, for different baselines.

\begin{tabular}{|c|c|c|c|c|}
\hline Zone & $\begin{array}{l}\text { day-degrees } \\
\text { Centigrade } \\
\text { (above } 0^{\circ} \mathrm{C} . \text { ) }\end{array}$ & \multicolumn{3}{|c|}{$\begin{array}{l}\% \text { of warmest zone for baseline } \\
0^{\circ} \mathrm{C} . \quad 2^{\circ} \mathrm{C} .\end{array}$} \\
\hline $\begin{array}{l}\text { pond bottom, } 4.0 \mathrm{~cm} \text {. water } \\
\text { pond bottom, } 9.0 \mathrm{~cm} \text {. water } \\
\text { pond bottom, } 18.5 \mathrm{~cm} \text {. water }\end{array}$ & $\begin{array}{l}147 \\
142 \\
139\end{array}$ & $\begin{array}{r}100 \\
97 \\
94\end{array}$ & $\begin{array}{r}100 \\
95 \\
92\end{array}$ & $\begin{array}{r}100 \\
89 \\
82\end{array}$ \\
\hline $\begin{array}{l}9.0 \mathrm{~cm} \text {. water, pond bottom } \\
4.0 \mathrm{~cm} \text {. water, } 1 \mathrm{~cm} \text {. mud } \\
9.0 \mathrm{~cm} \text {. water, } 2 \mathrm{~cm} \text {. mud } \\
9.0 \mathrm{~cm} \text {. water, } 5 \mathrm{~cm} . \text { mud }\end{array}$ & $\begin{array}{l}141 \\
144 \\
124 \\
76.5\end{array}$ & $\begin{array}{c}100 \\
98 * \\
88 \\
54\end{array}$ & $\begin{array}{c}100 \\
97^{*} \\
81 \\
31\end{array}$ & $\begin{array}{c}100 \\
84^{*} \\
56 \\
3\end{array}$ \\
\hline ground surface & 148 & - & - & - \\
\hline
\end{tabular}

*of the value for the bottom under $4.0 \mathrm{~cm}$. water; $1 \mathrm{~cm}$. mud temperatures under a depth of $9.0 \mathrm{~cm}$. are not available.

For the lower baselines the differences between different water depths were small (Table 2) and the top layer of bottom mud also received almost as much heat as the water immediately above it. For the $0^{\circ} \mathrm{C}$. baseline, the difference over the top $2 \mathrm{~cm}$. was about the same as would be produced between the mud surface at the edge and that at the centre of the pond by the later thawing of the centre. Below the top 1 to $2 \mathrm{~cm}$., however, there was a marked falling off in heat received and only about half of that at the mud surface reached a depth of $5 \mathrm{~cm}$. Furthermore, at this depth in the mud, exposure to temperatures above $4^{\circ} \mathrm{C}$. was negligible. 


\section{DISCUSSION AND CONCLUSIONS}

The results show that the thawing of this shallow arctic pond takes place rapidly once it begins (Fig. 3). Thereafter the daily difference in mean temperature between zones at different depths decreases as the season progresses and the deeper substrate thaws (Fig. 4). In such habitats the mean water temperature exceeds the screen air temperature by several degrees (Oliver and Corbet 1966).

For a pond of this size the edge thaws only a few days before the centre; in larger deeper water bodies the differences from place to place are much greater. The differences between similar habitats with different exposures may also be large.

There is a distinct diel pattern in all zones (Figs. 5 and 6), even during the thaw. The effect of permafrost, which lies near the surface in the spring, can also be seen (Fig. 7). In the spring compared to the early summer the daily minimum in deeper habitats is earlier because the frozen ground near the surface pulls the temperature down more rapidly. The maximum is later in the deepest zone because the temperature rise is slowed for the same reason. The effect of permafrost in producing water temperature gradients has been noted before (Haufe 1957). Early in the season, both maxima and minima are lower in deeper zones (Figs. 5 and 6). Oliver and Corbet (1966) by comparing records for surface and bottom water over successive short intervals, showed that as the season progresses such a relationship disappears and the maximum is then lower and the minimum higher in the deeper zone where changes are buffered.

The ground surface temperature - which indicates the micro-climate in which most terrestrial arctic arthropods live - although more variable, has a mean (in this exposed situation) of $5.9^{\circ} \mathrm{C}$. (p. 117) which is remarkably similar to the pond water temperatures. This similarity is probably largely due to the general cloudiness during much of the period of measurement, for in this zone the heating effects of insolation are most marked (Geiger 1965), and a greater difference would be expected. Corbet (1967), using the same instrument and type of probe, measured markedly higher ground surface temperatures near Lake Hazen, Ellesmere Island, in a fairly sunny season, the mean for 18 to 24 June being $14^{\circ} \mathrm{C}$. The generally dull weather on Bathurst Island during the present study was partly due to the position of the pond in a valley running between two inlets of the sea, and partly to the break-up of large areas of open-sea ice earlier than in most seasons, facilitating the formation of mist and clouds.

The upper 1 to $2 \mathrm{~cm}$. of mud are almost as warm (for the month following the thaw) as the bottom water (Table 2), despite the underlying permafrost. The direct absorption of solar heat by the upper bottom material is doubtless a contributory factor where the water is shallow (and see Pichler 1937; Geiger 1965). Lower layers are much colder. The similarity of the bottom-water and surfacemud temperature summations for low baselines (Table 2) suggests that the water temperature at the pond bottom (which is the easiest zone in which to site sensors accurately) is a good indicator of conditions in the superficial substrate layers where most organic activity and growth occurs.

The extraction and analysis of hourly records to obtain pond temperatures is 
very time-consuming, and Oliver and Corbet (1966) tested the validity of using the maximum-minimum midpoint (which is easily derived) in place of the daymean, for pond studies. They examined the difference between these parameters for 65 records for a "surface" and 68 records for a "bottom" habitat. They found that the agreement was rather close; that the surface temperature showed poorer agreement than the bottom temperature; that the midpoint more often exceeded the day-mean than otherwise, since a pond heats up a little more rapidly than it cools down.

The records analysed here confirm these conclusions (Table 1), but also show that unusual days - when the normal diel pattern is disturbed - may produce quite large errors. Nevertheless, Oliver and Corbet's (1966) conclusion that the maximum-minimum midpoint is a satisfactory substitute for the true day-mean, particularly for bottom temperatures and for seasonal studies where running means might be used, is confirmed.

Ecologically significant processes such as growth and development generally involve temperature thresholds below which the processes do not occur (Allee et al. 1949, pp. 110-11). The relatively low temperatures of the mud layers of the pond bottom suggest that such thresholds are highly important to benthic organisms in the Arctic. The activity threshold of chironomid larvae from the pond lay at $0^{\circ} \mathrm{C}$., or below in artificially supercooled situations, so that they would have been active immediately after thawing. The threshold for pupation in one of the species (Stictochironomus sp.) was about $4{ }^{\circ} \mathrm{C}$. (personal observation). The baselines of Table 2 must therefore approximate thresholds for some of the pond species found, although the chironomids of deep arctic lakes perhaps develop at temperatures very close to freezing; even so the life-cycle takes more than one year (Oliver 1968). Even in shallow ponds life-cycles of more than one year are usual. The low day-degree values demonstrated for this type of rather easily warmed, and hence relatively favourable, habitat (although for part of a single rather unfavourable year) indicate why this should be so.

The low temperature sums in Table 2 suggest that the conventional definition of a "growing season" based on a threshold of $42^{\circ} \mathrm{F}$. $\left(5.56^{\circ} \mathrm{C}\right.$.) (e.g., Boughner 1964 ) is of limited value in the Arctic (see Downes 1964, p. 281), even for habitats like that studied. Redefinition of the growing season for the Arctic in terms of $32^{\circ} \mathrm{F}$. $\left(0^{\circ} \mathrm{C}\right.$.) (Downes 1965, p. 258$)$ seems desirable. Even if all temperatures above $0^{\circ} \mathrm{C}$. permit development, the heat available to organisms in arctic habitats is low. Together with the day to day fluctuation (Fig. 4) which operates in the Arctic close to thresholds of animal growth and activity, it reflects in these pond habitats the possibility of the marked differences from season to season for which the Arctic is well known. The simplest temperature measurements for shallow lentic habitats which would allow meaningful and reliable seasonal comparisons are the daily maxima and minima at the water-substrate interface.

\section{ACKNOWLEDGEMENTS}

I should like to thank the following for their assistance: Dr. D. R. Oliver for the loan of the thermistor thermograph; Mr. P. S. Taylor for help in the location of the pond; the Entomology Research Institute, Ottawa, the Polar Continental Shelf 
Project, and the National Museum of Canada (Natural Sciences) for logistic support; Mr. J. A. Downes and Dr. D. R. Oliver for helpful criticism of the manuscript; and the National Research Council of Canada for a Postdoctorate Fellowship which was held whilst this work was carried out.

\section{REFERENCES}

ALleE, W. C., A. E. EMERson, O. PARK, T. PARK and K. P. SChMidt. 1949. Principles of Animal Ecology. Philadelphia and London: W. B. Saunders Co. 837 pp.

BOUGHNER, C. C. 1964 . The distribution of growing-degree days in Canada. Canadian Meteorological Memoirs, 17: 1-40.

CORBET, P. S. 1965. An insect emergence trap for quantitative studies in shallow ponds. Canadian Entomologist, 97: 845-48.

1967. Further observations on diel periodicities of weather factors near the ground at Hazen Camp, Ellesmere Island, N.W.T. Defence Research Board, Canada, Directorate of Physical Research (Geophysics), Operation Hazen No. 31; 14 pp. +30 figs.

DowNEs, J. A. 1964. Arctic insects and their environment. Canadian Entomologist, 96: 279-307.

1965. Adaptations of insects in the arctic. Annual Review of Entomology, 10: 257-74.

GEIGER, R. 1965. The climate near the ground. Cambridge, Mass.: Harvard University Press. $611 \mathrm{pp}$.

haUFE, w. o. 1957. Physical environment and behaviour of immature stages of Aedes communis (Deg.) (Diptera: Culicidae) in subarctic Canada. Canadian Entomologist, 89: $120-39$.

Oliver, D. R. 1968. Adaptations of Arctic Chironomidae. Annales Zoologici Fennici, 5: 111-18.

OLIVER, D. R. and P. S. CORBET. 1966. Aquatic habitats in a high arctic locality: the Hazen Camp Study area, Ellesmere Island, N.W.T. Defence Research Board, Canada, Directorate of Physical Research (Geophysics), Operation Hazen, No. 26, 115 pp. +267 Figs.

PICHLER, w. 1937. Temperaturmessungen an einem Tümpel. Bioklimatische Beiblätter, $4: 25-27$.

VOISEY, P. W., R. S. ADHAV, A. W. THOMLINSON, and D. C. MACDONALD. 1964 . A portable thermistor thermograph. Engineering Research Service, Canada Department of Agriculture, 21 pp., 24 plans. 